\title{
Can good corporate governance practices contribute to firms' financial performance? - evidence from Malaysian companies
}

\author{
Allan Chang Aik Leng* \\ Department of Business and Management \\ University of Brunei Darussalam, Bandar Seri Begawan, Brunei \\ E-mail: alchang@fbeps.ubd.edu.bn \\ *Corresponding author
}

\section{Shazali Abu Mansor}

Faculty of Economics and Business

Universiti Malaysia Sarawak, Malaysia

E-mail: mshazali@feb.unimas.my

\begin{abstract}
This paper examines the impact of corporate governance practices and structures on the performance of firms in Malaysia. An empirical study was conducted based on data involving 120 Malaysian-listed companies over a four-year period from 1996 to 1999. This period encompassed the 1997/98 Asian financial crisis, which affected most countries in the Southeast Asian region including Malaysia. Due to the combination of cross-sectional and time-series data, panel data regression techniques were used to analyse performance of the firms using both fixed effects and random effects models. Using Return on Equity (ROE) as the dependent variable, it was established that the size of firm, gearing ratio (borrowing) and dominant CEOs (Chief Executive Officers) significantly influenced the performance of firms. The impact of size on the performance of firms followed a quadratic fashion with performance increasing with the size of the firm up to the optimal size of around 7,729 million Malaysian Ringgit (RM). Beyond that, firm performance declined with increasing size. Borrowing had a negative effect on earnings with $1 \%$ increase in borrowing having a $0.13 \%$ decrease in ROE. Finally, CEOs who are also chairman of the board exert a positive influence on company earnings. The study suggests that dominant CEOs could increase performance of firms when they dominate the decision-making process in their companies.
\end{abstract}

Keywords: corporate governance; board practices; board structure; firm performance.

Reference to this paper should be made as follows: Chang Aik Leng, A. and Abu Mansor, S. (2005) 'Can good corporate governance practices contribute to firms' financial performance? - Evidence from Malaysian companies', Int. J. Business Governance and Ethics, Vol. 1, No. 4, pp.350-362.

Biographical notes: Allan Chang Aik Leng has an MA in Accounting and Finance (Lancaster), FCCA (UK), ACMA (UK), is a Lecturer in accounting and finance at University of Brunei Darussalam. He has just submitted his $\mathrm{PhD}$ thesis and this article is a brief summary of the findings of the four-year study. $\mathrm{He}$ has been a lecturer for 17 years and was formerly a lecturer at University Technology MARA, where he lectured for 12 years. Mr. Chang is a qualified chartered certified accountant and had been working in the private sector for six years prior to joining the university as an academician. 